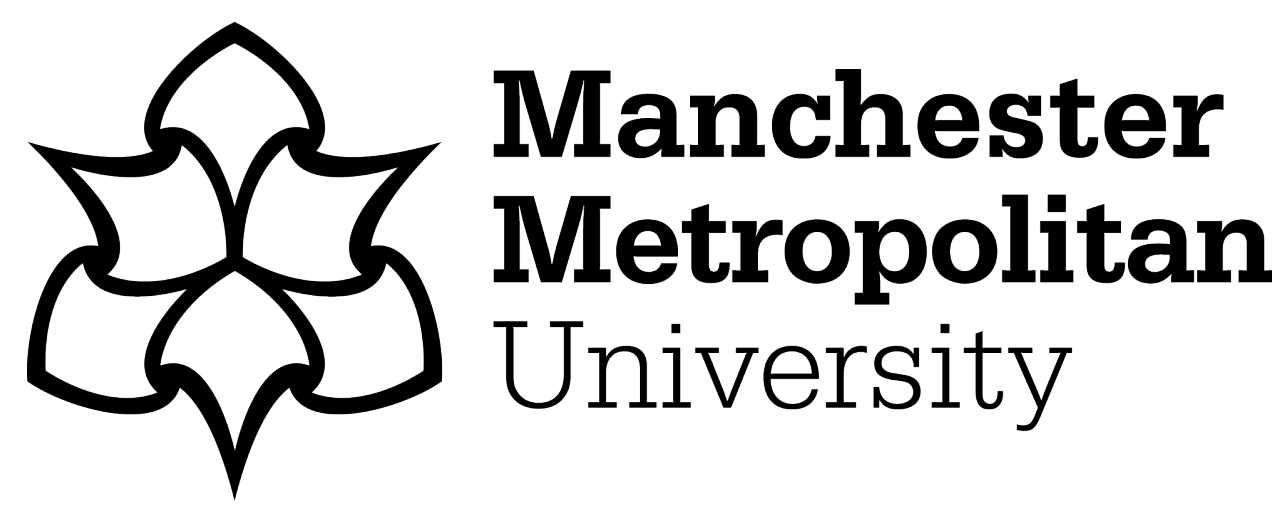

Cromwell, Jennifer ORCID logoORCID: https://orcid.org/0000-0003-02281371 (2020) On Erring Monks, Literacy, and Materiality: A Re-edition of O. Crum VC 6. In: Text Editions of (Abnormal) Hieratic, Demotic, Greek, Latin and Coptic Papyri and Ostraca. Papyrologica Lugduno-Batava, 37 . Brill. ISBN 9004438645

Downloaded from: https://e-space.mmu.ac.uk/627000/

Version: Accepted Version

Publisher: Brill

DOI: https://doi.org/10.1163/9789004439009

Please cite the published version 


\title{
$54-55$
}

\section{On Erring Monks, Literacy, and Materiality: A Re-edition of O. Crum vc 6}

\author{
Jennifer Cromwell
}

It is a great pleasure to be able to contribute to this volume in honour of Cisca, whose great generosity and kindness I have benefitted from over the years. I hope that the topics raised in this re-edition and the extended commentary - religion, social life, legal practices, literacy, and materiality - appeal to Cisca's diverse interests in papyrology and late antiquity.

\section{Introduction}

In 1939, Walter Crum published his final collection of Coptic non-literary documents. Varia Coptica contains 129 texts, for the most part on ostraca (hence its sigla O. Crum VC), with 19 on papyrus, written in the Sahidic and Fayumic dialects, and deriving from multiple sites. The first half of the volume contains translations of the texts, without commentary except for some philological notes, while the second half contains the transcriptions. The inclusion of translations is quite unusual for Crum's Coptic volumes, and as he notes in his preface to the volume: 'I have this time attempted in every case a translation, but mostly with poor success. Coptic documents, whether contracts or letters, even when flawlessly preserved, seem fated to remain here and there obscure.' ${ }^{\prime}$ As a result of the nature of the publication, the sometimes rough translations, and the lack of commentary, many important documents have remained overlooked and largely neglected over the past 8 o years. This point is true of the vast majority of Coptic documents published in the nineteenth and first half of the twentieth century.

The document presented here is one of the papyri from this collection: O. Crum vc 6 recto and verso. Crum did attempt to highlight the text in his preface, including it

\footnotetext{
1 O. Crum vc, p. 5 .
}

as part of his list of texts 'to which it may be worth drawing attention'. Yet, how he describes the papyrus, simply as 'no. 6 two ecclesiastical texts', woefully understates the importance of this document. From eighth century western Thebes, it contributes significantly to our understanding of monastic life in the area and demonstrates the necessity of paying attention to the material aspects of the manuscript. Despite this, it has barely made an impact on the scholarly literature on these topics. ${ }^{2}$ For these reasons, a new study of the two texts is presented here, accompanied by a revised edition of the original text, as it is possible to make some corrections to the edition and improve the translation, and the first publication of images of the papyrus.

The papyrus was acquired by the British Museum in 1924 and is now housed in the British Library, as part of the Asian and African collection. Crum noted its provenance as Djeme, the village built in and around Medinet Habu in western Thebes, based on prosopographic connections within the text and its reference to the 'mount

2 As far as I am aware, its main use has been to help identify the monastic complex at Deir el-Bachit as that of Apa Paul (see following note), based on the names of the superiors and without any detailed discussion of the text itself. It was also included as a documentary example of the practice of paired monks in monastic communities in C. RAPP, Brother-Making in Late Antiquity and Byzantium: Monks, Laymen, and Christian Ritual (Oxford, 2016), p. 112. Most recently, see E. GAREL, 'Vouloir ou ne pas vouloir: Devenir moine à Thèbes aux VII ${ }^{\mathrm{e}}-\mathrm{VIII}{ }^{\mathrm{e}}$ siècles d'après les textes documentaires', in: A. Boud'Hors - C. Louis (eds), Études coptes XV, Dix-septième journée d'études (Lisbonne, 18-20 juin 2015) (Paris, 2018), pp. 245-254, and A. BouD'hors, ‘À la recherche de normes monastiques en Égypte: L'apport des sources coptes documentaires', in: O. Delouis - M. MossakowsKa-Gaubert (eds), La vie quotidienne des moines en Orient et en Occident $\left(I V^{e}-X^{e}\right.$ siècle $)$ Volume II: Questions transverales (Cairo, 2019), pp. 415-432. The former discusses the texts in the context of documentary evidence for monks entering communities, including a partial translation, while the latter discusses aspects of monastic authority and provides translations of both the recto and verso. 
of Djeme'. However, the papyrus is not from the village but the monastery of Apa Paul at Deir el-Bachit. Walter Till first proposed its connection with this monastery 60 years ago and the document has since been used to help identify the complex at Deir el-Bachit as being that of Apa Paul. In both instances, the text has been somewhat tentatively used as evidence, but the archival history of the document confirms this provenance (discussed below). ${ }^{3}$ Based on what is known about the chronology of the superiors of the monastery, these two documents have been dated to the mid- to late 73 os (also discussed below).

\section{Description}

H. $\times$ W. $=36.0 \times 36.5 \mathrm{~cm}$. The papyrus is complete with only a few small lacunae and some areas of wear, especially on the verso, and a series of brown vertical lines on the recto that were created at the time of production. The first document was written at the beginning of the papyrus roll, with the Greek-Arabic protokollon still attached to it. ${ }^{4}$ The text is written transvera charta (i.e. across the vertical fibres), in contrast to the sheet bearing the protokollon, which has horizontal fibres. Excluding the protokollon, there is one kollesis, located above line 14 and now mostly obscured by a crack in the papyrus at this point. To write the second document on the verso (along the horizontal fibres), the papyrus was flipped over its bottom edge, resulting in the writing on this side being at $180^{\circ}$ to that on the recto.

The same individual,Johannes (patronymic notknown), wrote both documents. Johannes' hand is discussed further below; in terms of details, the only significant point is that $\mathrm{N}$ can sometimes resemble $\mathrm{M}$, when it is stretched out and the diagonal stroke curls at the end. The text is written in the Sahidic dialect, and there is little to note in terms of its language. A small number of words have non-Sahidic variations, exhibiting Akhmimic (i.e., Lycopolitan) tendencies: Ma2€ (recto line 6; S. Mood) 6 ), NaX = (recto line 9; S. No $x=$, but note the Sahidic writing on verso line 12 ), and

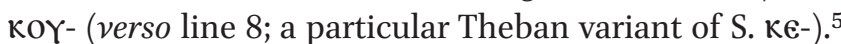
Apart from some unusual abbreviations, and occasional omission of the first person singular suffix, the main point to highlight is orthographic inconsistency across the two documents (and at times within the same document) concerning some personal names and Greek words, for example: Theodoros occurs as өєळторос (recto line 2),

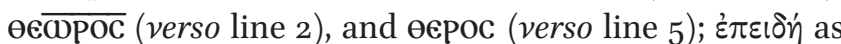

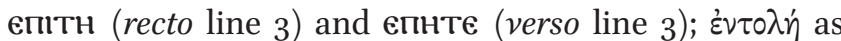

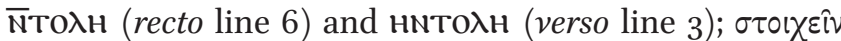
as стнхе (recto line 14) and стнүхє (verso line 13); ن

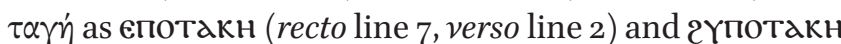

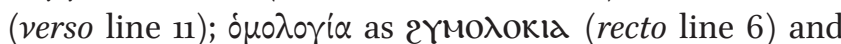
2Ім0入огіd (verso line 13). Regarding variations of personal names, I have retained a single spelling in my translation in order to avoid confusion. Johannes consistently uses diacritic marks, in particular the superlinear stroke over syllabic $\bar{N}$ and $M \bar{N}$, often differentiating the writing of the stroke between the two: over consecutive syllabic $\overline{\mathrm{N}}$, the stroke is a small arch, whereas over a single syllabic $\bar{N}$ it is a straight line; and when over $M \bar{N}$, the stroke is primarily over $n u$, but also partially over the preceding $m u$. Additionally, the diaeresis is used over iota when it follows another vowel. These uses of the superlinear stroke and diaeresis are fairly common among Theban writers.

3 Till, Prosopographie, pp. 47 and 236; T. BeCKH - I. Eichner S. HODAK, 'Briefe aus der koptischen Vergangenheit: Zur Identifikation der Klosteranlage Deir el-Bachît in Theben-West', MDAIK 67 (2011), p. 22.

4 I do not here provide a transcription of the protokollon, which was added to the roll at the time of its production, for which see the editio princeps. The text mentions 'Abd al-Azīz b. Marwān, governor of Egypt between 685-705 (meaning that the papyrus was manufactured over 30 years before it was used to write these documents).

5 For -, see H. WINLOCK - W.E. CRUM, The Monastery of Epiphanius at Thebes. Part I: The Archaeological Material; The Literary Material (New York, 1926), pp. 247-248: 'A form characteristic of the Theban idiom?. 
British Library Or. 9536 recto

Monastery of Apa Paul (Deir el-Bachit), 735-738 CE

TM 83739

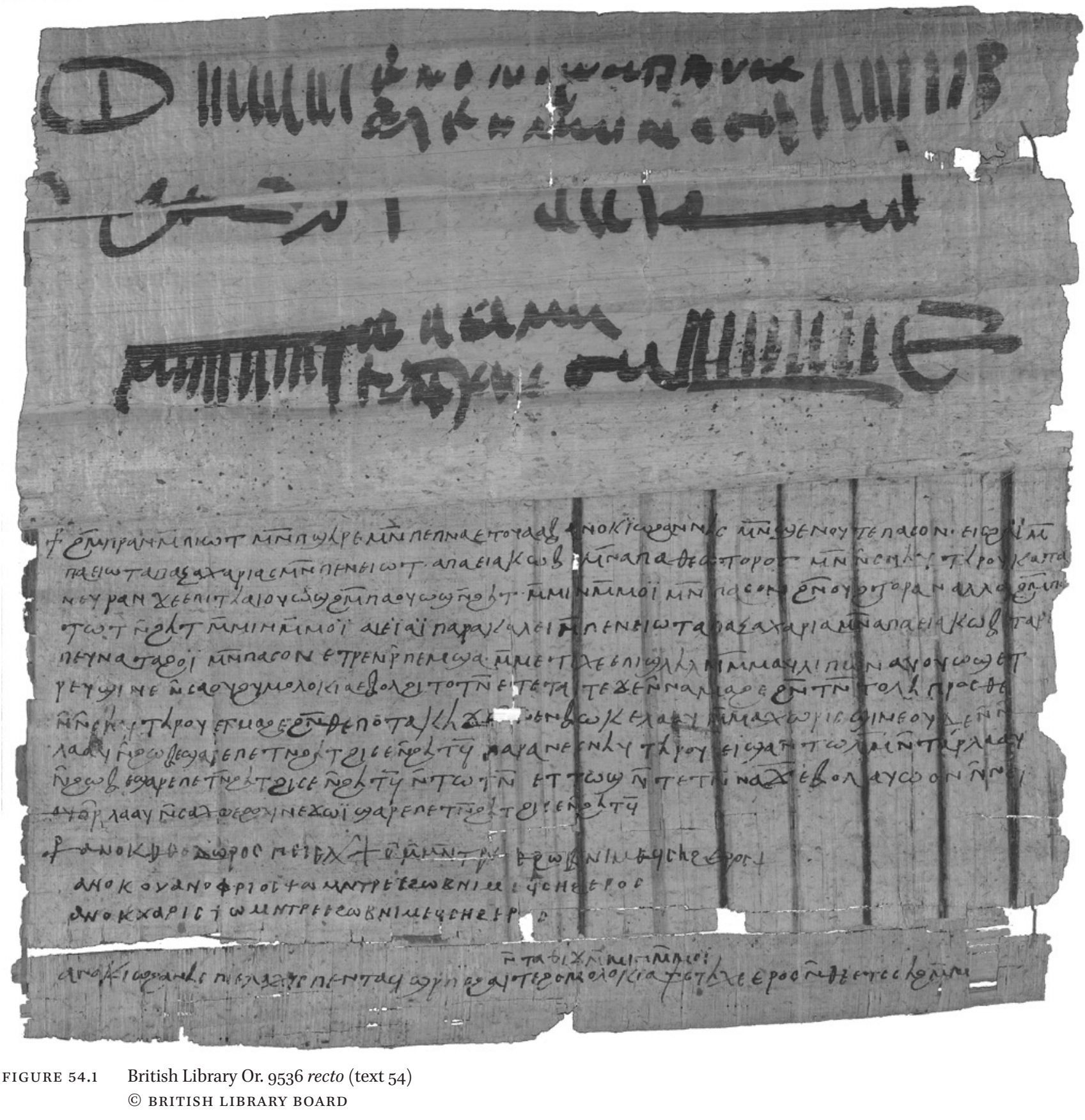




\section{Transcription}

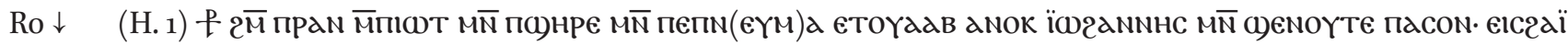
$\overline{\mathrm{M}}-$

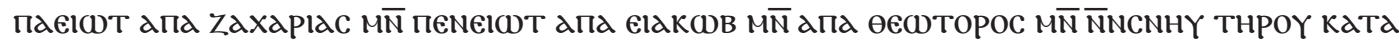

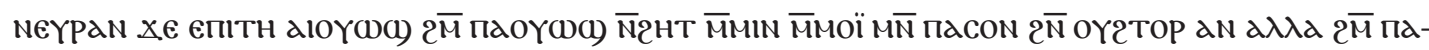

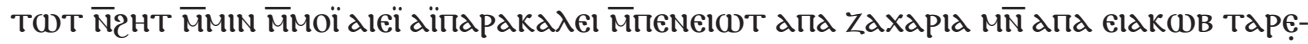

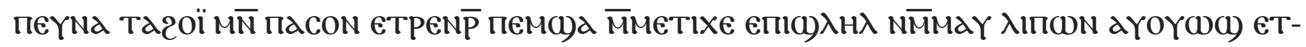

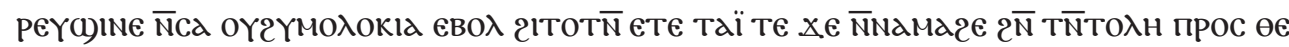

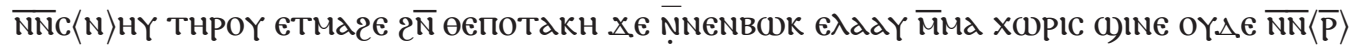

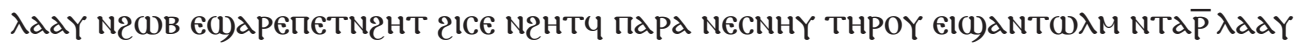
N2

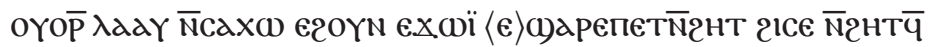

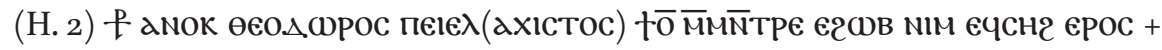

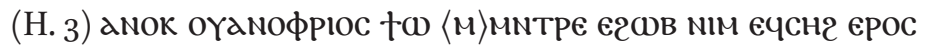

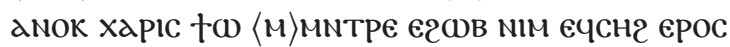

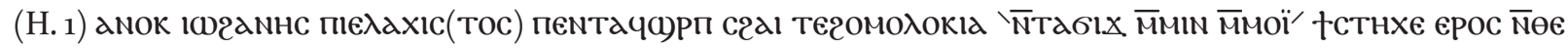
етсснг $\bar{M} M[\mathrm{OC}]+$

Docket, verso:

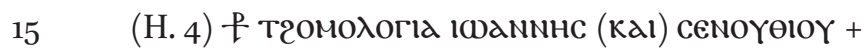

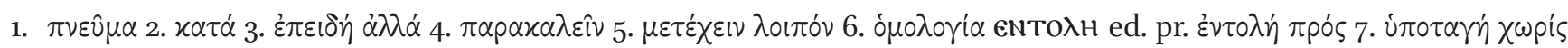

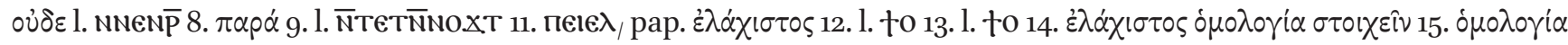
s pap. $x \alpha i$

\section{Translation}

(Hand 1) ' $\mathrm{f}$ In the name of the Father, the Son, and the Holy Spirit. I, Johannes, with my brother Shenoute, write to my Father Apa Zacharias, and our Father Apa Jacob and Apa Theodoros, with all the brethren individually.'

'Since I wanted, through my own express desire, with my brother - not through necessity but through my own consent - I came and requested our Father Apa Zacharias and Apa Jacob, so that their mercy may reach me and my brother so that we may be worthy to join them in this prayer. However, they wanted to ask for a declaration from us, namely that we will proceed in the ordinance, as all the brethren who proceed in obedience, that we shall never go anywhere without asking, nor (do) anything that upsets you, more so than all the brethren. If I defile (myself) or do anything that upsets you, you are the ones who command and expel (me). Furthermore, I shall never allow any sachô (to have authority) over me, lest it upsets you.'

(Hand 2) ' $\mathrm{f}$ I, the most humble Theodore, bear witness to everything written. +'
(Hand 3) 'I, Onophrios, bear witness to everything written.'

'I, Charis, bear witness to everything written.'

(Hand 1) 'I, the most humble Johannes, who already wrote the agreement 'by my own hand', I consent to it, according to what is written. +'

(Docket, hand 4) 'f The declaration (of) Johannes and Shenoute. +'

\section{Commentary}

5-6 The editio princeps provides a very confused translation of these lines, considerably rearranging their word order and duplicating certain sections: 'whereupon ( $\dot{\varepsilon} \tau \iota \tau$ i $\alpha$ ) (on me?), namely to cast (me) forth, I besought thy paternity and thou, my father, Apa Karire and Apa Theodore, didst desire to inflict the punishment certain reliable elder brethren .... The error seems to be one of cut-and-paste, with Crum inverting his translation of the ends of lines 6 and 7 , with that of line 5 . 
$7 \mathrm{C}\langle\mathrm{N}\rangle \mathrm{H}\rangle: \mathrm{H}$ appears to be written over an initial $\mathrm{N}, \quad 11$ creating an error.

10 caxo: on this term, see the recent discussion in Boud'hors, 'À la recherche de normes monastiques en Égypte', in: La vie quotidienne des moines, p. 419, which summarises the difficulty in determining its meaning. While she notes that in some contexts it appears simply to refer to an important person, perhaps with ecclesiastic authority, ultimately the term 'mérite décidément une étude détaillée.' As such, I leave the term here untranslated, as does Boud'hors in her translation of this text (p. 427). Whoever the sachô here is, they are not to have any influence or authority over Johannes (for oYwp2 eqoYn, see CRUM, Coptic Dictionary, p. 491b, with oYō- one of several variants of the pre-nominal form of the verb).
$12-13$

15

5 The editio princeps transcribes this line at the end of the text on the verso, noting that it belongs to the text on the recto. In so doing, the editio princeps obscures the function of this line, which is a docket to the original document, written in a different hand to Johannes'. Johannes' second document, written entirely on the verso, is at $180^{\circ}$ to this single line of text. For this reason, I transcribe it as belonging to the text on the recto, rather than simply another line on the verso.

тгомологі⿱: The article, $\mathrm{T}$-, is written in a very unusual form, in one motion of the pen such that it resembles a $\gamma$.

British Library Or. 9536 verso

Monastery of Apa Paul (Deir el-Bachit), 11 August 738 (?) CE

TM 83740

\section{Transcription}

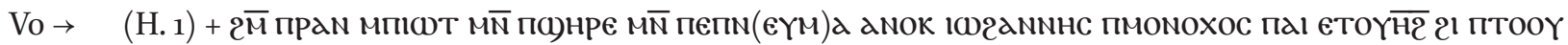

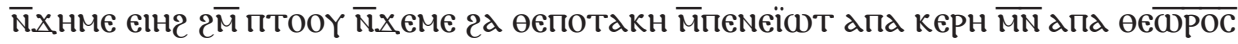

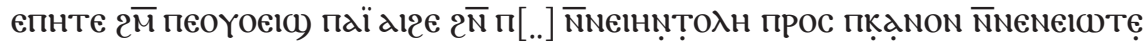

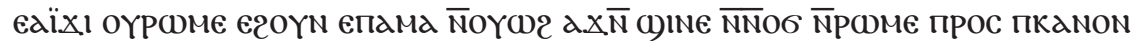

5 мNल

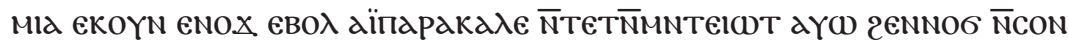

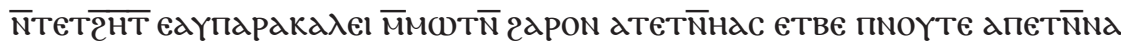

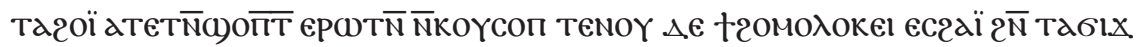

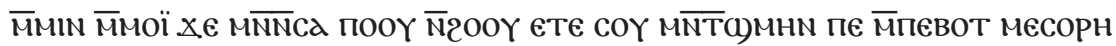

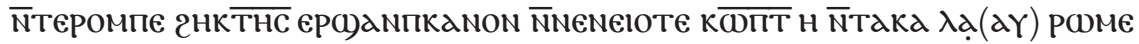

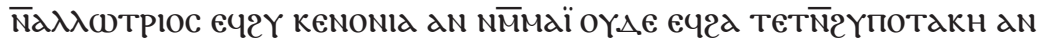

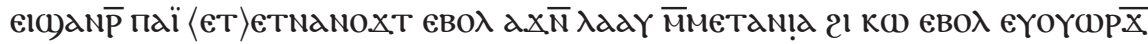

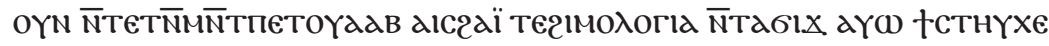
EPOC

(H. 2) + aNOK еПффаNIOC †ст(H)x(є) епіегграфоN +

(H. 3) + аNOK Аגүеiт по)не мүате тіо ммNтре + + aNOK петрос по)не NКОMес т10 MMNTPE +

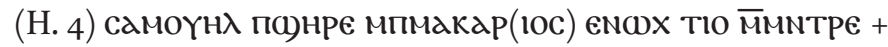




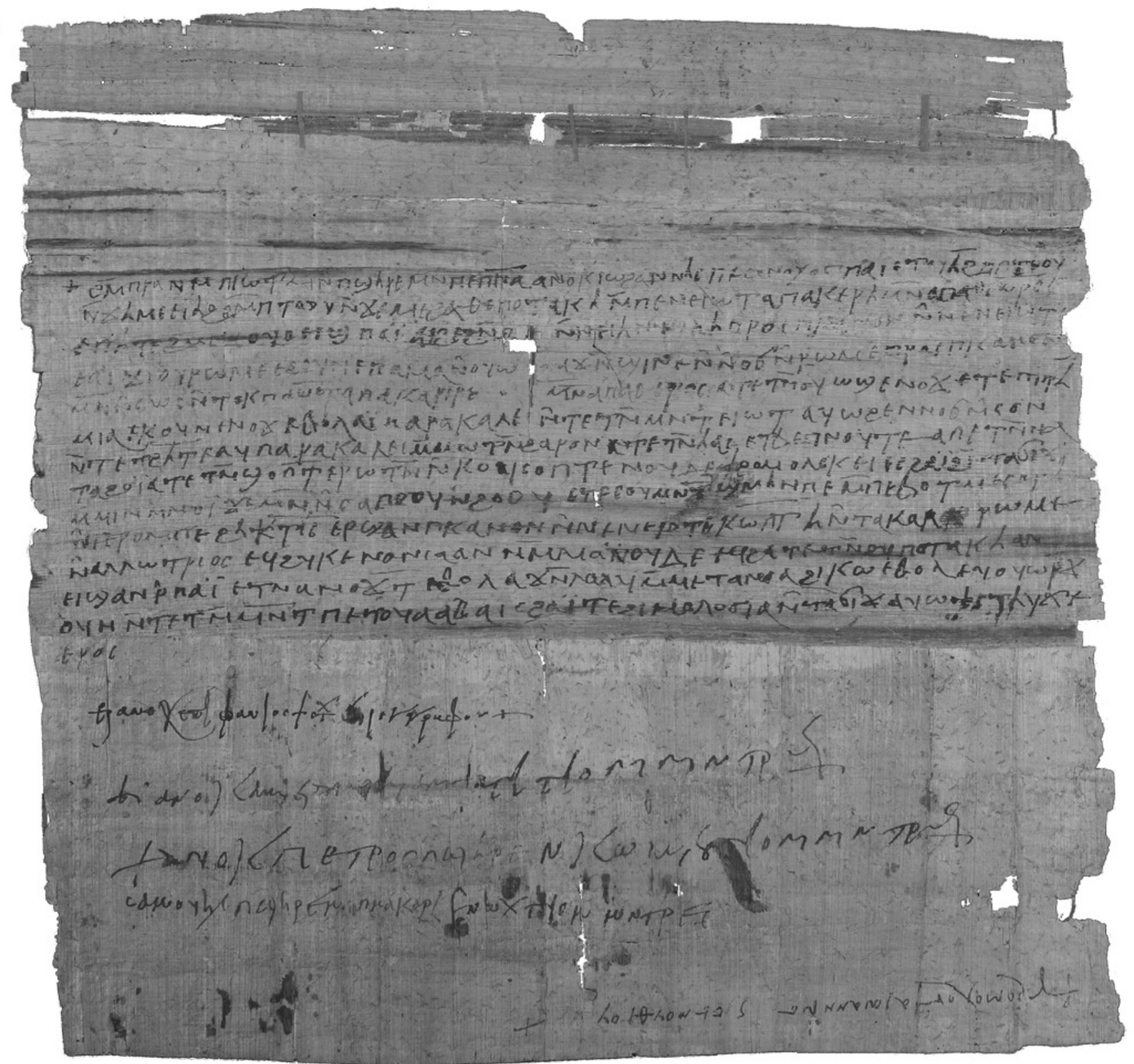

FIGURE 55.1 British Library Or. 9536 verso (text 55)

(C) BRITISH LIBRARY BOARD

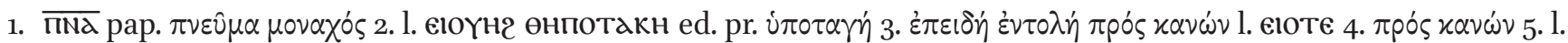

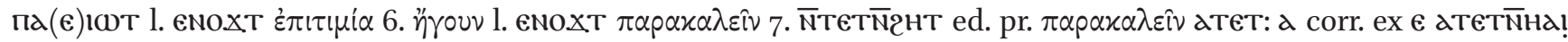

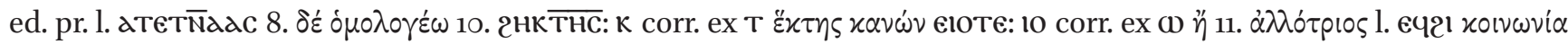

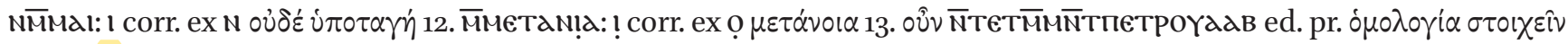

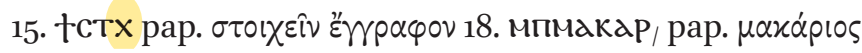




\section{Translation}

(Hand 1) + 'In the name of the Father, the Son, and the (Holy) Spirit. I, the monk Johannes, who lives in the mount of Djeme, living on the mount of Djeme under the authority of our Father Apa Kyre and Apa Theodoros.'

'In this time, I fell into the [...] of these ordinances, according to the canon of our Fathers, having brought a man into my cell without asking the elders, in accordance with the canon. Afterwards, you, my Father Apa Kyre with Apa Theodoros, wanted to inflict the punishment, namely, to cast (me) out. I begged your paternity, and some senior, consenting brothers having urged you on our behalf, you acted, for God's sake, and your mercy reached me, and you received me to you again. Therefore, I now declare and write by my own hand that, from today the 18 Mesore of year 6, if the canon of our Fathers seizes me, or I keep any strange man, who is neither in fellowship with me nor under your authority, if I do this, you will expel me, without any repentance or forgiveness. As a surety, then, (for) your holiness, I have drawn up this declaration by my own hand and consent to it.'

(Hand 2) '+ I, Epiphanius, consent to this document. +' (Hand 3 ) '+ I, David the son of Psate, bear witness. +

+ I, Petros the son of Komes, bear witness. +'

(Hand 4) '(I,) Samuel the son of the late Enoch, bear witness. +'

\section{Commentary}

1 Johannes has forgotten єтоүадв 'holy' after $\overline{\pi N d .}$ пMONOXOc: $\mathrm{x}$ is a correction over, but the original letter is not easy to identify what was written єाн 2 $2 \bar{M}$ птоо $\overline{\mathrm{N}} \times € \mathrm{M} \epsilon$ : the editio princeps comments 'Why this is repeated incorrectly is not clear. No change of hand'. It is possible that Johannes is offering greater specificity here with the circumstantial construction (in contrast to the previous relative

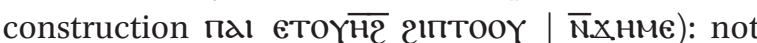
only does he live on the mount of Djeme, he specifically lives on the mount under the authority of Apa Kyre and Apa Theodore.

$32 \bar{N} \Pi[.$.$] : as there is only space for two letters here,$ reconstructing $\mathrm{Nd}$, 'mercy', would seem appropriate. However, the intended meaning here is surely to fall away from the ordinances rather than 'into' them, as necessitated by the preposition $2 \overline{\mathrm{N}}$. Neither the editio princeps nor BOUD'HORS, 'À la recherche de normes monastiques en Égypte', in: La vie quotidienne des moines, p. 427, reconstruct this passage, although the former translates the preposition as 'from'.

At the end of the line, there is a descending, curved stroke and it is not clear whether this belongs to something after חKaNoN, such as a cross, or to the end of line 5 (which seems less likely).

6 For eкоҮN as ทैrouv, see examples collected in FÖRSTER, Wörterbuch, p. 323. These attestations occur in other Theban texts as well as those from the Hermopolite nome and Aphrodito.

8 коүсоп: $\curlyvee$ is a correction over what may have been originally $\mathrm{c}$.

$10 \quad \kappa d \lambda d(\lambda Y)$ : a messy correction has been made here after $\kappa \lambda$, with $\lambda$ being written over a small letter and what appears to be $\alpha$ over what may originally have been $\omega$, but this is not certain.

$\langle$ eT $\rangle$ eTNanoxT: Johannes has made an error, and either the I Future (TETNanoxt) or II Future (єтетNanoxт) is required. The latter seems more likely, on the basis of haplography and the appropriateness of a focalising construction here, emphasising that Johannes will be expelled without repentance nor forgiveness.

meTdNid: 1 appears to be a correction, possibly of a small o; the resulting letter is short and fat.

Without a patronymic, it is not possible to identify this Epiphanius; the style of his cursive hand, with long vertical strokes, suggests he may be a professional (village) scribe.

16 David son of Psate is a well-known scribe from Djeme (see the further discussion below). For David, see TIll, Prosopographie, p. 74; T.S. Richter, 'Zwei Urkunden des koptischen Notars David, des Sohnes des Psate', AfP 44 (1998); and J.A. Cromwell, Recording Village Life: A Coptic Scribe in Early Islamic Egypt (Ann Arbor, 2017), pp. 183-185.

It is possible that this Petros son of Komes is the same man who occurs as a witness in P. CLT 1, 114 (where he also is unable to sign in his own hand) and who is attested elsewhere as a senior village official. However, given the approximately 40 years between the two documents (P. CLT 1 is dated 698) - and the common nature of both these names - it is possible that a different individual is involved. For occurrences of various individuals called Petros son of Komes, see Till, Prosopographie, pp. 171-172.

18 A Samuel son of Enoch appears as a senior official (dioiketes) in P. KRU 71 (dated to 765 by TILL, Prosopographie, pp. 27-28) and as a witness in several documents in the 730s, including P. KRU 106, 
which also concerns the monastery of Apa Paul; see TILl, Prosopographie, pp. 193-194.

\section{Entering a Monastic Community}

Pachomian Rule 49 details the procedure required for admittance of new monks to the community. The entrant is to be taught the Lord's prayer and as many psalms as he can learn over a few days, after which he must explain to the superior his reasons for wanting to join the community, in particular that his motivation is not to avoid legal or personal issues in the secular world. If the applicant is then able to renounce both his family and worldly possessions, he will receive instruction in the monastic way of life and be permitted to enter into the community. ${ }^{6}$ From the monastery of Apa Phoibammon at Deir el-Bahri, multiple letters to bishop Abraham (early seventh century) concern ordination as deacons or priests and state the stipulations in place. ${ }^{7}$ Documentary evidence for entering monasteries is more scant, as Wipszycka notes: 'The moment of joining a monastic community is only very rarely documented in the papyri.' 8 To her knowledge, only four such documents exist, two from the sixth century Aphrodito archive of Dioscorus son of Apollo, ${ }^{9}$ and two from western Thebes: O. Vind. Copt. 287 and O. Brit. Mus. Copt. II 8. In the first of these Theban texts, the sender requests that a novice be invested into the habit

6 For a full translation of the rule, see A. Veilleux, Pachomian Koinonia. Volume Two: Pachomian Chronicles and Rules (Kalamazoo, 1981), pp. 152-153; see also the discussion in E. WipszYcKA, The Second Gift of the Nile: Monks and Monasteries in Late Antique Egypt (Warsaw, 2018), pp. 341-343. Note that Wipszycka, op. cit., is in part an updated version of her earlier monograph, E. WIPSZYCKA, Moines et communautés monastiques en Égypte (IV ${ }^{e}-V I I I^{e}$ siècles) (Warsaw, 2009); for this rule and the material discussed in the following notes, see especially pp. 365-381 ('Comment devenait-on moine?').

7 See, for example, O. Crum 29-35 and ad. 7. In these documents, the most common statement is that the applicant will observe the हvं०-

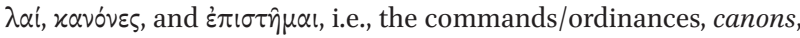
and regulations. The first two terms are mentioned in our text.

8 Wipszycka, Second Gift, p. 246.

9 WipszyckA, Second Gift, p. 247 mentions only P. Cairo Masp. II 67176 + P. Alex. inv. 689. This document has a duplicate: P. Cairo Masp. III 67353, which must be the unnamed second document that she mentions. Therefore, there is only one relevant document from Aphrodito. On these duplicate documents, which still await their first full edition, see J.-L. Fournet, 'Sur les premiers documents juridiques coptes', in: A. BouD' Hors - C. LouIs (eds), Études coptes XI: Treizième journée d'études, Marseille, 7-9 juin 2007 (Paris, 2010), pp. 125-137 (the document that Wipszycka mentions actually comprises many more fragments than the two named). and declares that he will cancel a debt that the novice owes him. In the second, two men write to a monastery of Besammon, reiterating their earlier request to join and promising to adhere to the canons. ${ }^{10}$ Note, however, that in this latter text the two men, Petros and Solomon, are already monks, not new initiates.

Somehow, O. Crum vc 6 has fallen through the cracks, even though it provides the clearest documentary evidence of the process. ${ }^{11}$ Upon Johannes and Shenoute requesting to join the monks, they are asked first to provide a declaration - Johannes' first document. The primary component of this declaration is obedience: they will observe the ordinances ( $\dot{\varepsilon} v \tau 0 \lambda \alpha i$ ) and not act in any way that upsets the superiors. There is no statement of legal status, nor any mention of financial concerns, whether debt to another or renunciation of their possessions to the monastery. This lack of mention of property stands in contrast to a primary concern found in the rules of Shenoute, the famous abbot of the White Monastery at Sohag. Here, not only is it the case that both men and women wishing to be monks should hand over all their belongings, they should ideally also write a document confirming their actions. ${ }^{12}$ As no actual such contract survives from Shenoute's monastery, whether or not documents were drawn up in practice cannot be verified. That the Theban contract does not mention property may be a reflection of the varying concerns of different communities; or, it may reflect specific concerns in this instance. ${ }^{13}$

10 These points are, however, mostly reconstructed by the original editor of this ostracon, Biedenkopf-Ziehner (including the reference to canons and informing the superior). As such, the edition should be treated with more caution than WiPSzYCKA, Second Gift, p. 348 affords it.

11 Note that this study was completed before GAREL, 'Vouloir ou ne pas vouloir' in: Études coptes $X V$, became known to me (I would like to thank an anonymous reviewer for drawing my attention to it). Garel mentions O. Crum 6 recto and verso in connection with becoming a monk (pp. 246-247); further documentary evidence for becoming a monk in western Thebes includes unpublished material that she is preparing for publication.

12 Rule 243: 'And any who comes to us to become a monastic whether male or female, shall first renounce all the things that they possess unto the Diakonia as soon as they are at the gatehouse ... they shall sign over every article that they have brought ... It would be proper for them to do so in writing before entering the gatehouse ...' (text and translation in B. LAYTON, The Canons of Our Fathers: Monastic Rules of Shenoute [Oxford, 2014], pp. 190-191; note that these rules are extracted from Shenoute's writings, rather than a systematic set of regulations, and their numbering is that given to them by Layton).

13 Note, though, that the narrative component of P. KRU 65, the testament of Jacob (superior of the Monastery of Apa Phoibammon), describes how his successor, Victor, entered the 


\section{An Erring Monk}

The original declaration by Johannes and Shenoute is not dated, while the second was written on 18 Mesore (11 August) of a sixth indiction year. Although no absolute dates are recorded, the prosopographic record allows the second document to be dated 738 , while the former was written in or after $735 .{ }^{14}$ How long it took Johannes to lapse in his observance of the community's rules cannot, therefore, be precisely determined; it may be a case of months or a couple of years.

Johannes explicitly states the nature of his offense: he brought a man into his cell without asking the elders first for permission (verso line 4). But which aspect of this situation in particular is the issue: breaking sleeping regulations, homosexuality, or not seeking permission? On face value, the second of these options may seem to be the most likely. The surviving monastic regulations, i.e., those of Pachomius and Shenoute, are replete with rules and warnings against promiscuity and explicitly prevent close-quarter sleeping: 'And also, whoever, whether it be male or female, shall sleep in pairs on a tam-mat or whoever sleep at all close together, so as to touch and bump against one another with desirous passion, shall be under a curse' (Shenoute Rule 94). ${ }^{15}$ However, later in the text,

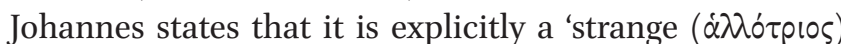

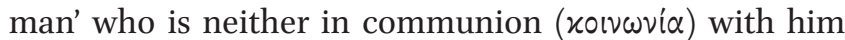
nor under the authority of the superior that would pose a problem. This detail alludes to the practice of monastic pairs living as part of larger communities, a practice attested in both the literary and non-literary record, and condoned by monastic superiors. ${ }^{16}$ While the focus of this papyrus becomes Johannes, it needs to be remembered that in the first instance he applied for entrance to the community together with his 'brother' Shenoute. The use of kinship terminology in monasticism obscures whether

community; see GAREL, 'Vouloir ou ne pas vouloir', in: Études coptes $X V$, pp. $245^{-246 .}$

14 See Till, Prosopographie, p. 47 for the suggested date of $735^{-738}$ for the first text and 738 for the second, which is based on his reconstruction of the superiors of the monastery of Apa Paul (see n. 4).

15 Text and translation in LAYTon, Canons of our Fathers, pp. 126 and 127. See also Shenoute's rules 1, 2, 3, 47, and 96 concerning physical contact during sleeping, and Pachomian regulations $87,88,89,94,107$, as well as 95 and 109 , which concern physical proximity in other situations (translations in VEILLEUX, Pachomian Chronicles and Rules).

16 See RAPP, Brother-Making, for a detailed analysis of this practice across the late antique Mediterranean world (pp. 108-115 cover some of the documentary evidence for paired monks). the two men were biological brothers, ${ }^{17}$ potentially with a paired living arrangement (the lack of patronymics is particularly frustrating in this instance) or if they were a monastic pair. ${ }^{18}$ There is no mention of Shenoute in the second document, and it is unclear whether his absence means that he was not involved in the situation (and so was not living with Johannes) or that his forgiveness was not the important factor as far as the community was concerned. Johannes only seeks forgiveness from the monastic elders.

Notably, the superiors Apa Kyre and Theodoros initially wanted to expel Johannes, but reconsidered after Johannes appealed to other senior monks of the community. Texts recording transgressions by monks are not uncommon, with the regulations imposed on monastic life being difficult for some to maintain. In O. Crum 294, Ezekiel writes to Apa Victor of the monastery of Apa Phoibammon, stating that if he again defiles the interior of the monastery (lines

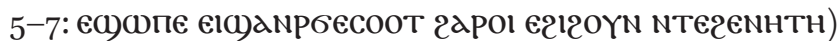
they may expel him and punish him publicly. Another text from the same monastery, O. Crum 300, contains a report of the repeated foolish behaviour (lines 4-5: and BIкTWP пема)нрє рмптсоб бєсоп) of one Apa Victor (not the superior addressed in the previous document!). Johannes is not alone in being afforded a second chance for errant behaviour. Where our text differs from other texts is in the explicit mention of the nature of the misdeed and the recording of the situation in a formal legal document, a contract written by the very individual at the heart of the issue himself.

\section{Literacy}

Ideally, all individuals entering a monastery would be literate, as stipulated in the oft-touted Pachomian Rule 139 ('And if he is illiterate ...') and 140 ('There shall be no one whatever in the monastery who does not learn to read ...'). ${ }^{19}$ The number of ostraca from monastic contexts

17 On the language of brotherhood in Christianity and monasticism, see RAPP, op. cit., pp. 6-9.

18 In the previously mentioned O. Brit. Mus. Copt. II 8, two monks together request to join the monastery - again, there are no patronymics, but there is no need to think of them as related. Note that this text is not included in the discussion of the documentary evidence in RAPP, Brother-Making, pp. 108-115.

19 Translations in Veilleux, Pachomian Chronicles and Rules, p. 166. On literacy in early monasticism, see now the collected works in L.I. LARSEN - S. RUBENSON (eds), Monastic Education in Late Antiquity: The Transformation of Classical Paideia (Cambridge, 2018) 
in western Thebes bearing school texts is seemingly testament to the amount of literacy education that took place in this environment. ${ }^{20}$ However, being sufficiently literate to be able to compose basic quotidian documents and write passages from the psalms is a far step removed from the ability to compose legal documents. ${ }^{21}$ O. Crum vC 6 demonstrates that Johannes was able to produce more complex texts. However, this is not to say that he was a professional documentary scribe. His hand is an advanced, regular, square hand that is quite common in letters, but it is considerably different from the type of contemporary professional (or at least administrative) Coptic hand that appears from the 720 s/73os (for example, that of David son of Psate who witnesses the second document, writing lines 16 and 17). ${ }^{22}$ Furthermore, while the texts on recto

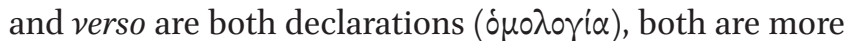
narrative in tone than legal, with only minimal use of legal formulae (verso lines 12-14 are a rare example).

Regardless of Johannes' background and training, the point remains that he was a highly literate individual. The amount of texts produced at the monastery of Apa Paul, as well as the Theban communities more generally, shows that there was a need for such people, who could write a range of texts that ensured the successful functioning of the monastery. ${ }^{23}$ In contrast to the monastery of Apa Phoibammon, scribes from the village Djeme were regularly involved in producing documents for the monastery of Apa Paul: the well-known scribe Psate son of Pisrael wrote both P. CLT 1 (dated 698) and 5 (dated 711/12), and his (probable) son, the aforementioned David son of Psate, witnesses the second of our two documents. It is difficult to say what this use of village scribes means for the monastery, whether it indicates a lack of in-house trained documentary scribes, or it reflects the monastery's wider

20 See R. Cribiore, 'The Coptic School Exercises in the Collection of the Columbia University', in: B. Palme (ed.), Akten des 23. Internationalen Papyrologenkongresses, Wien 22-28 Juli 2001 (Vienna, 2007), pp. 127-130, and J. CromWELL, 'Educating Western Thebes: Locating Centers of Schooling', in: A. MARAVELA Á.T. MıнÁLYkó (eds), New Perspectives on Religion, Education, and Culture in Christian Western Thebes (VI-VIII) (forthcoming). On the predominance and use of psalms in western Thebes, see A. Delattre, 'Between Education and Religion: Psalm Quotations and Compositions in the Theban Area', in: A. Maravela - Á.T. Minálykó (eds), op. cit.

22 Cromwell, Recording Village Life, discusses professional scribal practices at this time, see especially chapters 3 and 6 .

23 BECKH - HODAK - EICHNER, 'Briefe aus der koptischen Vergangenheit' discusses the previously known documents concerning the monastery of Apa Paul; the ostraca found during the course of the German excavation of the site are published online at https://www.koptolys.gwi.uni-muenchen.de/splash.php. networks. In support of the latter, the two witnesses to the second document are officials from Djeme: why would such men be involved in what is an internal issue for the monastery? ${ }^{24}$ Or, in this case, were these men - among the 'great men' of Djeme - present as character witnesses for Johannes? Such questions will go unanswered, as this text exists in isolation, as far as its protagonist is concerned. One further question, however, can be raised, even if it is not answered: was Johannes' literacy, in a world that relied on such skills, part of the reason why the superior changed his mind and gave Johannes a second chance?

\section{Materiality}

One final aspect of the document remains to be discussed: its non-textual features. Both the nature of the reuse and Johannes' palaeography contribute to our understanding of the production of the two documents, archival practices at the monastery, and Johannes himself. As already mentioned, the first document is written on the recto and happens to be from the beginning of the roll, as indicated by the presence of the bilingual Greek-Arabic protokollon. ${ }^{25}$ Johannes wrote the document, witnesses signed, and then Johannes wrote his signature. Altogether, the text fills the length of the papyrus (presumably, the papyrus was cut to length first). After the text was completed, a different individual turned the papyrus over and wrote a docket with the text at the same orientation as that on the recto The docket itself is an indication of archiving procedures, allowing the document to be found easily at a later date.

This ability to retrieve the document proved necessary, as it was later used for Johannes' second declaration (it is unlikely that Johannes retained the document for his own security - his declaration was made for the benefit of the monastery itself). Its reuse is therefore an indication of the efficient nature of the archival system in place; not only was the document found, but the fact that it was reused indicates that it was more sensible to have the documents literally together. A small number

24 For Petros son of Komes and Samuel son of Enoch, see the above commentary to the recto (lines 17 and 18 ).

25 These protokolla are preserved on a number of Theban documents - the practice in Thebes seems to have been to keep them rather than cut them off to reuse them; on this point, see Cromwell, Recording Village Life, p. 8. The question remains why this was the case. Perhaps, the presence of the protokollon gave a perceived extra air of authority (even though it had nothing to do with the content of the document itself) and was therefore a highly valued addition to the beginning of any document 
of texts from Deir el-Bahri refer to a $\beta \iota \beta \lambda ı 0 \eta \dot{\eta} \kappa \eta$, not a library in this instance but a location in which documents could be stored. ${ }^{26}$ In this respect, it is important to know the acquisition history of this papyrus. It was acquired by the British Museum in 1924, together with two other documents from the monastery of Apa Paul: P. CLT 5 and O. Crum vC $7 \cdot{ }^{27}$ Also in this year, five papyri, P. CLT $1-4$ and SB III 7240, were acquired by the Metropolitan Museum of Art, New York, all of which concern the monastery. ${ }^{28}$ Together, the close acquisition dates of these seven documents confirms that they were originally part of the same Apa Paul archive. ${ }^{29}$

Beyond its layout and reuse, Johannes' palaeography is interesting across the two sides of the papyrus. The second document is notably not as carefully-written as the first. On one hand, this point can be explained on the basis of the worse quality of the papyrus on the verso the papyrus was not made so that each side provided a good writing surface, with attention being given to the recto (i.e., side with vertical fibres) only. It may be of note that Johannes had a choice concerning on which part of the papyrus that he wrote: writing at $180^{\circ}$ to the text on the recto, he wrote on the back of the first sheet of the roll, not on the back of the protokollon sheet. If he had done the latter, he would have written across the fibres

26 See the references in Cromwell, Recording Village Life, pp. 6o-61.

27 The acquisition record, now in the Asia and Africa reading room in the British Library, records no details about this group. Walter Crum noted, in his Notebook 77 in the Griffith Institute (Oxford), that these papyri entered the Museum in June 1924 and were handed to the Egyptian Department in winter of the same year.

28 SB III 7240 was published separately from the other Apa Paul texts by H.I. BELL, 'Two Official Letters of the Arab Period', JEA 12 (1926) pp. 265-281 (not only is it written in Greek, it was also written to the monastery by the pagarch Atias son of Goedos), but they were part of the same acquisition by the Metropolitan Museum of Art.

29 The value of museum archaeology can be used to confirm original provenance; for those unfamiliar with the principles, see K. VAndorpe, 'Museum Archaeology or How to Reconstruct Pathyris Archives', in: E. Bresciani (ed.), Acta Demotica. Acts of the Fifth International Conference for Demotists. Pisa, 4-8 September 1993 (EVO 17, Pisa, 1994), pp. 289-300, and K. VANDorpe - S. Waebens, Reconstructing Pathyris' Archives. A Multicultural Community in Hellenistic Egypt (CollHell 3, Brussels, 2009), pp. 65-73. and his handwriting would immediately have been of better quality (compare, for example, the finer quality of the witnesses' statements, which are written on this part of the document). Was Johannes paying attention to what he was doing, did he even care?

On the other hand, however, the quality of the papyrus is not entirely to blame for his penmanship. Overall, his hand has the appearance of being hastier: it is irregular, in terms of the consistency in letter-size and line evenness. His spelling is erratic within the document, including variant orthographies of the same word (Хнмє versus хємє on line 2; aпג кєрн on line 2 versus and карıрє on line 5; епотакн on line 2 versus 2үпотакн on line 11), and there are several corrections on the verso (often minor slips that are immediately corrected), but none on the recto. The impression of these combined features is not only one of haste, but of Johannes' agitated state-of-mind. It is not difficult to imagine him having to write this document - admitting his original behaviour and reaffirming his initial declaration - while the superior and witnesses (men of high standing with the wider Theban community) surrounded him, making sure that he recorded the details of the situation accurately. Palaeography is not always simply a by-product of the practical act of writing. Paying close attention to this metatextual data can often reveal much more than the words themselves can in isolation.

\section{Summary}

Published 80 years ago, these two documents have suffered the same fate as many early editions of Coptic non-literary texts. Largely inaccessible to non-specialists, their significance has largely been overlooked and they have not been incorporated into the scholarly literature to the extent that they should (or could) have been. In particular, these documents contribute to our understanding of monasticism in a local, Theban context, and monasticism more generally, in terms of entering communities and punishing - and forgiving - erring monks. Additionally, the texts provide insight into scribal practices, and possibly even the scribe's mindset, as well as archival strategies. While many new texts await their first edition, the nature of Coptic documentary papyrology is such that many texts that have been published in the early decades of the discipline are also in need of renewed attention. 